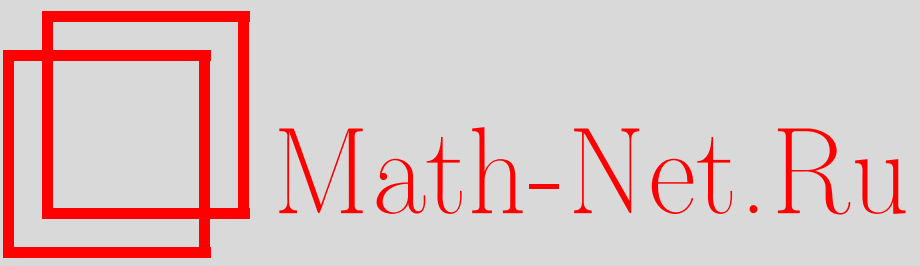

А. Л. Лукашов, Д. И. Трубецков, П. Л. Ульянов, А. П. Хромов, Восьмая Саратовская зимняя школа "Современные проблемы теории функций и их приложения", УМН, 1996, том 51, выпуск 3, 221-222

DOI: https://doi.org/10.4213/rm1566

Использование Общероссийского математического портала Math-Net.Ru подразумевает, что вы прочитали и согласны с пользовательским соглашением

http://www.mathnet.ru/rus/agreement

Параметры загрузки:

IP: 3.95 .254 .165

26 апреля 2023 г., 18:02:39 


\section{ВОСЬМАЯ САРАТОВСКАЯ ЗИМНЯЯ ШКОЛА “СОВРЕМЕННЫЕ ПРОБЛЕМЫ ТЕОРИИ ФУНКЦИЙ И ИХ ПРИЛОЖЕНИЯ"}

\footnotetext{
С 30 января по 6 февраля 1996 года под Саратовым на левом берегу Волги проходила восьмая Саратовская зимняя шккола "Современные проблемы теории функций и их приложения", организованная Московским государственным университетом имени М.В. Ломоносова, Математическим институтом РАН им. В.А. Стеклова и Саратовским государственным университетом им. Н.Г. Чернышевского при финансовой поддержке Российского фонда фундаментальных исследований. В работе восьмой школы приняли участие 140 математиков из 28 городов России, Украины, Белоруссии. Среди участников школы были член-корреспондент РАН, 27 докторов наук, 60 кандидатов наук. Оргкомитет школы возглавили член-корреспондент РАН П. Л. Ульянов (председатель), член-корреспондент РАН Д. И. Трубецков (зам. председателя), профессор А.П. Хромов (зам. председателя), академик РАН С. М. Никольский, профессор, академик МАНВШН Е.П. Долженко, профессора Б.И. Голубов, Б.С. Кашин, Ю. Ф. Коробейник, Ю.В. Покорный, Д. В. Прохоров, Ю.Н. Субботин, В.А. Юрко, доцент А. Л. Лукашов (секретарь).

Было прочитано 3 лекции, посвященные памяти выдающегося русского математика, профессора, доктора физико-математических наук Сергея Борисовича Стечкина: П. Л. Ульяновым (Москва) "Воспоминания о Сергее Борисовиче Стечкине", С.В. Конягиным (Москва) "Вклад С.Б. Стечкина в развитие теории приближений", В.В. Арестовым (Екатеринбург) "Задача Стечкина о приближении неограниченных операторов ограниченными".

Для целостного представления о современном состоянии и существующих приложениях теории функций и указания возможных путей ее дальнейшего развития Оргкомитет заказал лекции продолжительностью 1 час. Было прочитано 11 лекций:

А. И. Абанин (Ростов-на-Дону), "Мультипликаторы и делители функциональных пространств и абсолютно представляющие системы";

В.М. Бадков (Екатеринбург), "Функция Сеге";

В.Ф. Гапошкин (Москва), "Об устойчивости почти всюду многопараметрических групп унитарных операторов";

В.А. Калягин (Нижний Новгород), "Анализ несимметричных операторов и аппроксимации Эрмита-Паде";

Б. С. Кашин (Москва), "Теоремы об ограничении операторов на координатное подпространство";

В. Г. Кротов (Минск), "Теорема о следах для функций из пространства Харди-Соболева";

С.Р. Насыров (Казань), "Краевые задачи со свободной границей на римановых поверхностях";

Ю. В. Покорньй (Воронеж), "Спектральная теория дифференциальных операторов";

А. П. Хромов (Саратов), "Об обращении одного класса интегральных операторов";
} 
И. И. Шарапудинов (Махачкала), "Об ограничении $L_{p}$-нормы алгебраического полинома по его значениям в узлах равномерной сетки";

В.А. Юрко (Саратов), "Обратная задача для дифференциальных операторов и ее приложения".

Занятия в школе проходили в две смены. В первой половине дня читались лекции, после обеда работали три секции, на которых были заслушаны 17 докладов и 81 научное сообщение. Список докладов таков:

Г. С. Балашова (Москва) "О банаховых пространствах бесконечно диффференцируемых функций";

А.С. Белов (Иваново) "О свойствах неотрицательных тригонометрических полиномов с монотонными коэффициентами";

А. П. Буланов (Обнинск) "Сходимость кратных степеней";

А. П. Буслаев (Москва) "Об экстремальной задаче Лагранжа-Кондратьева";

Э. М. Галеев (Москва) "Оценки поперечников функциональных классов";

Б. И. Голубов (Москва) "О преобразованиях Харди и Беллмана пространств $H^{\prime}$ и ВМО";

А. Л. Лукашов (Саратов) "О решении алгебраической задачи Чебышева-Маркова на нескольких отрезках";

Б. П. Осиленкер (Москва) "Формула следов для ортогональных полиномов с асимптотически периодическими рекуррентными коэффициентами";

В. А. Осколков (Москва) "Об одном свойстве выпуклых на полуоси функций и его примененияx";

В. А. Родин (Воронеж) "Сильные средние и осцилляция кратных рядов по мульипликативной системе";

В. С. Рыхлов (Саратов) "О полноте собтвенных функций полиномиальных дифференциальных пучков операторов";

В. А. Скворцов (Москва) "Мартингальные последовательности в гармоническом анализе. Теоремы замкнутости";

С. А. Степин (Москва) "Разложение по собственным функциям несамосопряженных краевых задач и граничные значения интегралов типа Коши. Число обусловленности базиса Рисса из корневых функций сингулярно возмущенных дифференциальных операторов";

С. А. Теляковский (Москва) "Асимптотические и порядковые оценки для рядов по синусам с выпуклыми коэффицииентами”;

В.И. Филиппов (Саратов) "Классификация функциональных систем в пространстве $L_{p}$, $p>0$ "

Н. Н. Холщевникова (Москва) "Применение малых кардиналов в математическом анализе";

И. А. Шевчук (Киев) "Формосохраняющее приближение".

Издаются тезисы школы, кроме того, к окончанию работы школы завершено осушествленное при финансовой поддержке Российского Фонда Фундаментальных Исследований издание трудов предыдущей, 7-й Саратовской зимней школы по теории функций и приближений (памяти профессора А.А. Привалова).

По общему мнению, школа прошла успешно, хотя большему представительству молодых ученых, аспирантов и студентов помешали финансовые трудности, переживаемые сейчас российской наукой. Остается надеяться на то, что в 1998 году очередная школа по теории функций состоится, как и запланировано, в окрестностях Саратова. 